\title{
"THUS CHANGED, I RETURN...": \\ THE PROGRAMMATIC PROLOGUE OF THE FIRST SURVIVING OPERA EURIDICE (1600) BY OTTAVIO RINUCCINI AND JACOPO PERI. EURIPIDEAN, SENECAN POETICS AND MUSIC AS REPRESENTATION
}

\author{
GEORgIOS P. TSOMIs*
}

Democritus University of Thrace

\begin{abstract}
Resumo. Não desconsiderando a influência da prática teatral renascentista, especialmente da "tragi-comedia pastorale", no nascimento e desenvolvimento da ópera, meu argumento é que Rinuccini tinha em mente o renascimento da tragédia antiga no Prólogo de Eurídice (1600), a primeira ópera que conhecemos, ciente de que sua produção não consistiu numa reconstrução historicamente acurada da antiga tragédia grega. Vemos no Prólogo que, de um lado, La Tragedia mantém em seu repertório olhares, lágrimas, lamentos de um ponto de vista puramente humano, desejando despertar no coração emoções mais prazerosas; de outro, ela propõe uma catarse por meio de um final feliz para a história. Eu não estou convencido de que, no Prólogo, nosso poeta rejeita o efeito catártico das tragédias gregas, nem que sua obra se coloque em oposição aos preceitos aristotélicos para a tragédia, como pensam muitos musicologistas e historiadores da música. Penso que, em um Prólogo que é na verdade uma recusatio, Rinuccini quer que sua Tragédia lance luzes sobre a natureza do prazer que a audiência obtém da experiência da tragédia. A ênfase de La Tragedia sobre o puramente afetivo tem a ver com certas características da dramaturgia de Eurípides, mais do que com a tragédia de Sêneca, que se tornou a força principal na moldura da tragédia renascentista.
\end{abstract}

Keywords. Ottavio Rinuccini; Jacopo Peri; Eurídice; prólogo; Eurípides; Sêneca.

D.O.I. 10.11606/issn.2358-3150.v0i16p61-83

IN RENAISSANCE THEATRE, ESPECIALLY IN PASTORAL PLAYS AND IN THE FIRST opera libretti we find prologues which apart from their expositional and explanatory function directly or indirectly convey the author's views of the art of drama and its genre presenting at the same time an author conscious of innovating. It is usually an allegorical or mythological figure who recites or sings the prologue, e.g. Mercury in Poliziano's La fabula d'Orfeo (1480), Cupid in Tasso's Aminta (1573), the river Alfeios in Guarini's Il pastor fido (1585). We also find this in the first favole in musica: Tragedy in Rinuccini's Euridice (1600), Music in Striggio's Orfeo (1607), Apollo in Rinuccini's und Monteverdi's L'Arianna and so on. These allegorical and mythological figures should

"Assistant Professor of Ancient Greek. Habilitated in Classics, Goethe-Universität, Frankfurt am Main.

“. Artigo recebido em 19.ago.2014 e aceito para publicação em 5.out.2014. 
be regarded as authorities who not only give a formal and eminent character to the opening of these dramas but, especially in the case of the first favole in musica, function as declaration of validity and raison d' être, a kind of manifesto and legitimization for the new genre, symbolizing or indicating the aesthetic ideals linked to the constitution of opera as a genre as well. ${ }^{1}$ Hence it was not unexpected that the prologue fell into disuse when opera had established itself. The prologue to Euridice (160o), the first surviving drama by Ottavio Rinuccini and Jacopo Peri as principal composer ${ }^{2}$ set completely to music from beginning to end, is performed by Tragedia (Tragedy). Its seven stanzas each consisting of four eleven-syllable lines with the rhyme scheme $a b b a$, provide important information about the new genre and its aesthetic. Tragedia's authority furnishes the new genre with a rhetorical intensity, the endecasyllabic verses emphasize the manifesto character of this prologue, lending to it a certain gravity and a festal tone as well, which is reinforced by Rinuccini's choice of words. ${ }^{3}$

Although the play is not divided into acts, it consists of five scenes, ${ }^{4}$ separated by choruses in strophic verse, hinting at the structure of the ancient tragedy. ${ }^{5}$ The first and the last scene with their festivity and joyfulness provide a frame. An expansive monologue dominates in each scene: Orfeo addresses a hymn to nature expressing his happiness, the nymph Dafne reports Euridice's tragic death, the shepherd Arcetro gives a detailed account of the epiphany of Venere and the rescue of Orfeo, Orfeo laments Euridice's death in the Underworld and back in the pastoral world the shepherd Aminta tells the good news i.e. Plutone has returned Euridice to Orfeo. The chorus takes the role of participants, nymphs and shepherds, during the scenes, while at the end of each scene it offers a commentary of the previous action as a "Greek chorus". The final scene ends with a ballo.

\footnotetext{
${ }^{1}$ On the function of the Prologue in the pastoral plays and on more examples see Hanning 1973 and Hansen 2003, esp. 573 ff.

${ }^{2}$ Giulio Caccini has also contributed to the music of Euridice.

${ }^{3}$ On the musical features that are characteristic of the arie of these Prologues see Hansen 2003, $573 \mathrm{ff}$.

${ }^{4}$ On the structure of Euridice see Bujić 1991, 34 ff.

${ }^{5}$ The opera opens with a singer representing the Tragic Muse, La Tragedia. In the first scene all of the nymphs and shepherds gather to celebrate the wedding of Orfeo and Euridice. In the second scene Orfeo is content after his wedding but is soon interrupted by Dafne. She brings the terrible news that Euridice has been bitten by a venomous snake and has died. Orfeo then vows to join her in the underworld. In the third scene Arcetro recounts that while Orfeo lay weeping, Venus, goddess of love, carries him off in her chariot. In the fourth scene Venus and Orfeo arrive at the gates of the underworld. Venus suggests that through his legendary voice he might persuade Pluto to return Euridice to life. Orfeo succeeds and is allowed to leave with his bride. In the fifth scene Aminta shares the good news that Orfeo is returning back with Euridice from the underworld, Orfeo and Euridice appear to their friends and all rejoice.
} 
Without denying the influence of Renaissance theatrical practice, especially the "tragi-comedia pastorale" on the birth and development of the opera, ${ }^{6}$ I argue that Rinuccini aims at a rebirth of the ancient Tragedy in his Prologue of Euridice, well aware that his production was not a historically accurate reconstruction of ancient Greek tragedy. As we will see from the Prologue, on one hand La Tragedia retains in her repertoire sighs, tears, laments from a purely human point of view wanting to awake sweeter emotions of the heart, on the other hand she aims at a catharsis through a happy end of the story. I am not convinced that our poet in his prologue rejects the catharsis effect of the Greek tragedies ${ }^{7}$ and that his opus stands in opposition to the Aristotelian precepts for tragedy ${ }^{8}$ as many musicologists and music historians think. ${ }^{9}$ In this Prologue, that is actually a recusatio, I think that Rinuccini wants his Tragedia to illuminate the nature of the pleasure that the audience derives from the experience of tragedy. The emphasis of La Tragedia on the purely affective has more to do with features of the Euripidean dramaturgy than the Senecan tragedy, which became the greatest force in the moulding of Renaissance Tragedy.

\footnotetext{
${ }^{6}$ I would generally maintain that the Opera had and has accepted influences from all sides. Cf. Leopold 2003, 10: "Was eine Oper sei, mag zu einem bestimmten Zeitpunkt an einem klar umgrenzten Ort für einen Moment der Gattungsgeschichte eindeutig gewesen sein; davor, danach und anderswo aber konnte alles ganz anders aussehen. Und vielleicht ist gerade dies die Stärke der Oper und das spezifische Merkmal, das ihre Kontinuität bis in die heutige Zeit garantiert: die Fähigkeit, eben nicht klar umrissen, nicht berechenbar zu sein, sondern chaotisch und regellos, unsystematisch und untheoretisch und deshalb offen für Einflüsse von allen Seiten."

${ }^{7}$ Cf. for instance Hansen 2003, 579: "Its seven stanzas (sc. of the Prologue to Euridice) provide important information about the new genre and its aesthetic which, in spite of the fact that it is Tragedia who recites Rinuccini's manifesto, has nothing to do with Aristotelian catharsis. As many have argued, the court opera should be seen as an expression of la tragicommedia's far milder aesthetic."

${ }^{8}$ As M. Treherne (2007, $40 \mathrm{ff}$.) points out, tragicomedy can be therefore seen as a legitimate genre insofar as it is perfectly reasonable to bring together certain elements from tragedy and comedy without offending Aristotles's theory. Guarini, the author of the first tragicomedia pastorale, Il pastor fido, in his theoretical work Compendio does not reject Aristotle, but rather redefines the ways in which Aristotle's Poetics should be read. Guarini held the opinion that Aristotle had written the Poet$i$ ics, not as a set of universal precepts, but as a distillation of the principles he found evident in the best of the poetry of his time, also opens up the important observation that audiences change, and that consequently the effect of theatre on the audience is bound to change too; the architectonic end of a play is inevitably subject to adjustment by the playwright. The value of a play is rather found in its effect on the audience. In presenting tragicomedy as a whole genre, complete in its own right, Guarini is insistent upon its dignity within the principles set out by the authority of Aristotle. Tragicomedy balances the extremes of tragedy and comedy, it does ensure a seemly moderation in the viewer.

${ }^{9}$ For instance Claude Palisca and Nino Pirrotta, the most influential historians of early opera, emphasize on the contribution of contemporary theatrical forms, such as masques, pastorals and comedies, to the dramatic form of the early opera. Palisca $(1968,29,36)$ thinks of a mixed genre and not of true tragedy. Rinuccini and his circle, who were "steeped in the classics", were well aware that the musico-dramatic form they created was not "a rebirth of ancient tragedy". See also N. Pirrotta 1954a, 188: "It was only the success of Dafne which emboldened Rinuccini to call Euridice a tragedy"; N. Pirrotta 1954b, 295; Hanning 1973, 241 a.o.
} 


\section{EURIDICE}

IL PROLOGO

LA TRAGEDIA

1. Io, che d'alti sospir vaga e di pianti spars'or di doglia, or di minacce il volto fei negl'ampi teatri al popol folto scolorir di pietà volti, e sembianti.

2. Non sangue sparso d'innocenti vene non ciglia spente di tiranno insano, spettacolo infelice al guardo umano canto su meste, e lagrimose scene.

3. Lungi via lungi pur da regi tetti simolacri funesti, ombre d'affanni, ecco i mesti coturni, e i foschi panni cangio, e desto nei cor più dolci affetti.

4. Or s'avverrà, che le cangiate forme non senza alto stupor la terra ammiri, tal ch'ogni alma gentil ch'Apollo inspiri del mio novo cammin calpesti l'orme.

5. Vostro regina sia cotanto alloro qual forse anco non colse Atene, o Roma, fregio non vil fu l'onorata chioma fronda febea fra due corone d'oro.

6. Tal per voi torno, e con sereno aspetto ne' reali imenei, m'adorno anch'io, e su corde più liete il canto mio tempro al nobile cor dolce diletto.

7. Mentre Senna real prepara intanto alto diadema, onde il bel crin si fregi, e i manti, e seggi degl'antichi regi del tracio Orfeo date l'orecchia al canto.

In the first stanza the personified Tragedia introduces herself to her audience with the emphatic Io but without mentioning her name. Her identification is achieved through a relative clause, in which La Tragedia mentions her preferences and consequently the emotions she always evoked in the people: She is fond (vaga) of loud sighs and tears with her face shed at some points with grief and at some with menaces. As a result of these she made ( fei) the faces and countenances of the people crowded in the large theatres turn pale with pity. The second stanza including the predicate of the main 
clause canto (v. 8) begins with strong negative expressions that denote the reluctance of Tragedy to sing stories with blood thirsty, heinous and macabre plots: "Nor longer of blood spilled from innocent veins, nor of eyes put out by the insane Tyrant, miserable spectacle to human sight, do I sing on a sorrowful and tearful stage." It is evident from the second stanza that La Tragedia does not discard her traditional role as songstress of mournful and doleful scenes but she foremost wants to exclude plots from her repertoire that are horribly gruesome, repulsive and disgusting and do not evoke feelings of sympathy with the audience. Nevertheless her stories remain "meste" and "lacrimose". At the beginning of the third stanza she banishes those gruesome and terrifying scenes, which she describes as "simulacri funesti" (portentous images) and "ombre d' affanni" (shades of torture and plague) predominantly from the royal house, where the drama will be presented: "lungi via, lungi pur da regi tetti". She turns herself to the audience and announces the modification she wants to make in her subjects and themes using a metaphor: "Behold, I change my gloomy buskins and dark robes and awake in the heart sweeter emotions." It is clear that in the second and the third stanza La Tragedia criticises and simultaneously discards the horrible and baleful scenes from her repertoire. She will continue to wear her buskins and robes, as reference to her ancient role, but not in dismal and grimy colours, that provoke dreadful and loathsome feelings. She elaborates her new aim, i.e. to awake in people's hearts not the pity and terror of old as most powerful emotions but that of sympathy - in Aristotelian terms tò $\varphi \imath \lambda a ́ v \theta \rho \omega \pi$ ov (Poet. 1452b38) - und as she states: "più dolci affetti".

It is obvious that La Tragedia thus criticises Renaissance Tragedy and above all Seneca, from whom the dramatists derived their inspiration by adopting Senecan form, rhetoric and sensational horrors. "Blood shed by innocent veins", "eyes put out by the insane Tyrant", "portentous images", "shades of torture and plague" are expressions that refer to the Senecan poetics of horror, monstrosity, of extreme psychological darkness and despair, of powerful obsessive passions. ${ }^{10}$ It seems that Rinuccini has in mind the play Thyestes, since the majority of the expressions of the second and third stanza refer to that play: e.g. the ghost of Tantalus in the Prologue. It is well known that the Renaissance dramatists were influenced by the Senecan ghost-prologues, taking the prologues of Thyestes and Agamemnon as models for scores of later plays. ${ }^{11}$ We can also mention the description of Atreus' sacrifice of Thyestes' sons, his cooking of their flesh and its con-

\footnotetext{
${ }^{10}$ Cf. recently Staley 2010, esp. 96 ff.

${ }^{11}$ Tarrant 2004 (1976), 158.
} 
sumption by Thyestes. Unlike the ancient Greek tragedy this play does not evoke sympathy for the victims of disaster. The horror with which Seneca presents the deliberations of Atreus far exceeds anything ever presented on the tragic stage. Atreus appears with excessive cruelty and shows a morbid desire for supremacy; he becomes horrific in his maniacal sacrificing of the youngsters and in his sadistic attitude to Thyestes. Shock dominates in this play because of Atreus' triumph at the end of the drama. Although Thyestes prays to the gods for punishment, they do not lend him a favourable ear. ${ }^{12}$ In Senecan plays the gods (if they exist) seem ineffective without mediating to prevent an evil. "Blood shed by innocent veins" can also refer to Hercules killing his wife and his children one by one in the fourth act of the homonymous tragedy or to Medea in the last act, who falls in rage as the furies induced by her brother's murder now possess her and kills one of her sons on stage, achieving her fullest vengeance by killing the other son in front of Jason. "Eyes put out by the insane Tyrant" is a clear reference to the description of Oedipus' self-blinding in act 5, where fear and horror in comparison to Sophocles appears in all their asperity ${ }^{13}$; "portentous images" remind of scenes of animal sacrifice and necromancy, that exaggerate and escalate the horror in the centre of Senecan Oedipus (acts 2 and 3), whereas "shades of torture and plague" allude also to the menacing Laius arising from the underworld in Oedipus, or to Juno in the prologue of Hercules, who appears like a bloodcurdling demon calling for powers from the world of darkness to aid her revenge against Hercules.

During the Renaissance Senecan manuscripts were relative common, while Greek ones were rare. The period from 1480 to 1540 marks the frequent publication of the Senecan tragedies, the making of the earliest vernacular translations for the press, the beginning of stage performances of his plays and the outgrowth of Senecan traits in original dramas. ${ }^{14}$ The knowledge of Seneca in the original and in Italian through books and stage is increasing. From 1541 to 1590 the characteristic type of the Italian Senecan drama,

\footnotetext{
${ }^{12}$ On this drama see Schiesaro 2003.

${ }^{13}$ Cf. vv. 958-79: “ardent minaces igne truculento genae / oculique uix se sedibus retinent suis; / uiolentus audax uultus, iratus ferox / iamiam eruentis; gemuit et dirum fremens / manus in ora torsit. at contra truces / oculi steterunt et suam intenti manum / ultro insecuntur, uulneri occurrunt suo. / scrutatur auidus manibus uncis lumina, / radice ab ima funditus uulsos simul / euoluit orbes; haeret in uacuo manus / et fixa penitus unguibus lacerat cauos / alte recessus luminum et inanes sinus, / saeuitque frustra plusque quam satis est furit: / tantum est periclum lucis? attollit caput / cauisque lustrans orbibus caeli plagas / noctem experitur. quidquid effossis male / dependet oculis rumpit, et uictor deos / conclamat omnes: 'parcite en patriae, precor: / iam iusta feci, / debitas poenas tuli; / inuenta thalamis digna nox tandem meis.' / rigat ora foedus imber et lacerum caput / largum reuulsis sanguinem uenis uomit."

${ }^{14}$ See also Barden 1985.
} 
created by Giovanni Battista Giraldi Cinzio, with his drama Orbecche (1541) dominates, varied towards a more Greek drama on the one hand, or towards a pastoral tragicomedy on the other. Seneca's domination of the new tragedy was definitely established, for Italy in any case, and consequently for the rest of Western Europe. Cinzio had fitted tragedy for the stage, he had made classical tragedy modern and public but his model was Seneca and he stirred up his contemporaries to have no other model but the Roman tragedian. ${ }^{15}$

The "royal roof" (v. 9) indicates the place, where Euridice was first performed: the Pitti Palace - as a part of the festivities marking the wedding of Maria de' Medici and Henri Iv of Navarre. It does not refer to the French Palace, since Henry IV could not be present at the festivities, since he was at war with Savoy. He sent the Prince of Belgrade as his representative. During the wedding ceremony by proxy, Grand Duke Ferdinand de' Medici, the uncle of the bride, assumed the bridegroom's role. Although Marie did not actually meet Henry IV until the December $9^{\text {th }} 1600$ in Marseille after a long and perilous journey to France, she is referred to as the queen since the wedding ceremony in Florence. "16 "Royal roof" and "royal glory" refer to the Medici Dynasty, who with the union of the half - Habsburg Medici bride and the French king as groom attempts another truce in the centuries of struggle for political hegemony in Europe between the two major dynasties. Euridice as a drama set in music intends to celebrate not only the wedding itself but also the historical and political achievements that precede the performance of the play. ${ }^{17}$ La Tragedia herself seems to be convinced of the successful outcome of these "cangiate forme", stressing her role as initiator and pioneer:

\footnotetext{
${ }^{15}$ As he says: "in my opinion, Seneca is superior to any and every Greek in the artistic propriety, the gravity, the decorum, the power and in the sententiae of all his tragedies". G. Lanson (1904, 547) named Seneca's tragedies "the operating manual" for sixteenth-century humanist tragedy (a still common view). Humanist interest in Seneca's tragedies developed early. Around 1300 the early humanists Lovati Lovato and Nicholas di Trevet wrote commentaries on Seneca's tragedies. This interest in the dramatist Seneca is due to his stoicism, a philosophy that taught that the human passions were the source of evil, something that was not dissimilar to the Christian philosophy of many medieval figures, nor was it unattractive to the early humanists. The writers of the earliest Renaissance tragedies imitated the literary style of Seneca. In 1315, Albertino Mussato was among the first to compose a tragedy in the senecan style. In his Ecerinis, a drama not for the stage but for a small group of readers who were to recite the play, Mussato drew his plot from recent historical events about the wicked deeds and downfall of Ezzelino da Romano, a thirteenth-century Italian despot. This play has five acts, a small cast, chorus of Paduans, and a boastful cruel protagonist. Around 1390 Antonio Loschi wrote an Achilles, and about 1429 Gregorio Correr a Progne. Seven other mixed Senecan plays appeared in Italy from 1377 to 1500. On the great influence of Seneca on the Renaissance Theatre see Lucas 2009 (1922), 78 ff.; Schild 1933, 14; Herrick 1965; Braden 1985; Boyle 1997, 141 ff.; Hill 2002, 327 ff.

${ }^{16}$ Cf. also Hansen 2003, 583.

${ }^{17}$ On Euridice's political meanings, metaphors and message - in Euridice Rinuccini actually allegorizes Florence's political health - see predominantly Harness 2003, 13 ff. For other opinions and views see Bujić 1991, 47 ff.; McGee 1982, 163-81; Kirkendale 1993, 202; Carter 1992, 204, 211 f.
} 
It will now happen, that the world will admire these changed forms not without great amazement. This admiration will be so great that every gentle soul that Apollo inspires will tread in the tracks of my new path.

The new Queen, for whose wedding this drama was composed, is now addressed to share this success and admiration, a praise which may surpass that of Athens or Rome ever had. By naming the two cities, where the ancient drama had flourished, La Tragedia indicates that thanks to her the Queen will gain an immense reputation and with her Florence, the new home of the revived Tragedy: "A not worthless ornament on the honoured hair, a frond of Phoebus between two crowns of gold." "Fronda febea," might be an allusion to Rinuccini's and Peri's Dafne, the first opera ever, which was presented in 1598. Apollo is also of special significance to the Medici in Florence, since his hallmark laurel tree and its leaves appear as symbol of the family's power and endurance. "Apollo's leaves" seem to imply Medici's wealth and status, and as a tribute to the royal couple Maria de Medici and Henry IV of France, whose regal attributes are described in the final stanza. ${ }^{18}$ With the last verse of the fifth stanza La Tragedia implies that not only the Queen but also her French husband will be renowned by her revival.

In the sixth stanza La Tragedia now addresses the royal couple: "For you I return and with a clear, calm and bright mien I, too, adorn myself for the royal wedding." Only in the sixth stanza do we hear of the happy event "reali imenei", during which the new opus of La Tragedia will be presented. It is clear that her decision to relinquish her previous role as a songstress of obscure and gloomy spectacles to inspire sweeter emotions in the heart of her audience implied by the expression "con sereno aspetto", is not made up ad hoc for this specific purpose of the royal wedding. This important incident rather offers the advantageous opportunity, the favourable time for her to introduce this alteration: "And I temper my song on pleasanter chords, sweet rejoice to the noble heart." This recalls the last verse of the third stanza: "desto ne i cor più dolci affetti".

The theme of this favola in musica, the story of Orpheus and Euridice is not announced until the last stanza of the Prologue. The seventh stanza is therefore an invitation to hear the song of the Thracian Orfeo, while the royal Seine (Paris) prepares to receive the new Queen. By announcing the theme of her play after having stated the cangiate forme, the changed forms, that take over from now on, La Tragedia attempts to give the listeners an idea of the genre. The audience that is familiar with Orpheus' myth real- 
izes that the dreadful, gloomy and horrible scenes will be left out, above all the part of the myth, in which the inconsolable Orpheus after the second loss of his wife and living as a recluse avoiding above all the company of women, is torn to pieces by infuriated Thracian Maenads. The fact that this performance is intended to celebrate the royal wedding indicates that the audience will expect a happy end of the story, fin lieto that is the reunion of the mythical couple. As Rinuccini in the Introduction of Euridice asserts:

Some may find that I have been too audacious in changing the end of the fable of Orpheus; but it seemed appropriate to me in these times of joy, and other stories told by Greek poets speak to my justification ${ }^{19}$; even our own Dante was daring enough to argue that Ulysses was drowned on his voyage, although Homer and the other poets had related the contrary.

The most important thing in this programmatic prologue is the decision of La Tragedia to evoke sweeter emotions in the hearts of her audience. She discards her ancient role only to the point that she excludes from her stories dreadful, hideous, abominable and macabre scenes, features suitable to the Senecan tradition than to ancient Greek tragedies. This would be accomplished through music - specifically, a song tuned to "happier strings". This idea is elaborated in Rinuccini's and Jacopo Peri's Preface to Euridice. The latter declared that he had aimed at "an intermediate course" lying between the slow and suspended movements of song and the swift and rapid movements of speech: "I judged that the ancient Greeks and Romans (who in the opinion of many were wont to sing their staged tragedies throughout) had used a harmony surpassing that of ordinary speech but falling so far below the melody of song as to take an intermediate form" ${ }^{20}$ From the expression

\footnotetext{
${ }^{19}$ Orpheus's descent into the underworld to bring his deceased wife back to the upper world is already known to Aeschylus in his drama "Bassarai", lost to us, and Euripides in his Alcestis (vv. $357 \mathrm{ff}$.). The latter suggests a happy return of both to the upper world. The Orpheus-Eurydice story may, in its original form, have been one of triumph over death. Not only Euripides but also most writers before Vergil, who refer to Orpheus' descent, state or imply that the mythic hero succeeded in resurrecting his wife. Hermesianax in a fragment from his Leontium (fr. 7, 8 ff. Collectanea Alexandrina), preserved in the Deipnosophistae by Athenaios (13.579 b-c), PseudoMoschus in the "Lament for Bion" (vv. 123 ff.) - here we hear for the first time the name of his wife, Eurydice, which she will henceforth always bear - and Diodorus Siculus (4.25.4) are good examples of the happy end of the story of Orpheus and Eurydice.

${ }^{20}$ Le Musiche di Jacopo Peri . . . sopra L'Euridice . . . (Florence, 1601 [1600, Florentine style]): "veduto che si trattava di poesia drammatica e che però si doveva imitar' col canto chi parla ... stimai che gli antichi Greci e Romani (i quali, secondo l'opinione di molti, cantavano su le scene le tragedie intere)..." in Solerti 1903, 45. Rinuccini follows Peri in his foreword to Euridice, when he states: "È stata opinione di molti, Cristianissima Regina, che gli antichi Greci e Romani cantassero sulle scene le tragedie intere; ma sì nobil maniera di recitare nonchè rinnovata, ma nè pur, che io sappia, fin qui era stata tentata da alcuno, e ciò mi credev'io per difetto della musica moderna, di gran lunga all'antica inferiore. (Many have held the opinion, most Christian Queen, that the ancient Greeks and Romans sang tragedies throughout on the stage. But such a noble way of
} 
"in the opinion of many" one can mention with certainty three names: Girolamo Mei, Vincenzo Galilei, and Francesco Patrici with the latter to claim on the basis of Aristotle's Problems 19.48: "the entire tragedy, which was composed of actors and chorus, was sung". ${ }^{21}$ It is obvious that especially Patrici's theory on ancient music would have been known to Rinuccini and Peri. ${ }^{22}$ To achieve this goal, Peri developed a musical version of dramatic declamation, which is the "stile rappresentativo" or "stile recitativo": this was the recitation of the dramatic text that was declaimed in a single-voiced melody (monophony); it would mirror the natural inflections, rhythms, and syllables of speech, and be accompanied by musical instruments. Most of Rinuccini's libretto in Euridice consists of versi sciolti: rhymed, freely alternating sevenand eleven-syllable lines, with the final accent most often on the penultimate syllable. This practice refers to the madrigal poetry, but unlike madrigals, Peri's work does not follow a contrapuntal composition regarding melody and bass line. Instead, the bass moves very slowly, with harmonic changes limited to major stressed syllables, selected to mimic the natural cadences of speech. The music responds to the rhythm, meaning, and feeling of each word and thought. The rhythm and pace of the voice is that of speech, retarding or accelerating, depending on the mood and the disposition of the characters, their hesitancy, excitement, or calm narration and conversation. The vocal range is limited, with many monotonous passages, while the variety

reciting has not been renewed, or even tried, by anyone. I believe that the blame is to be found in the inadequacy of modern music, which is so much inferior to ancient music.)

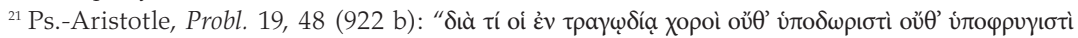

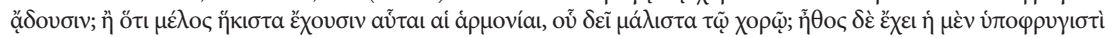

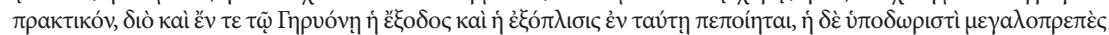

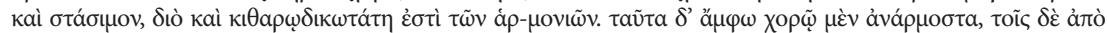

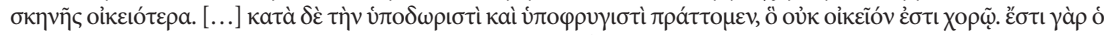

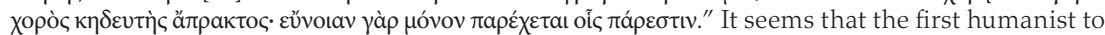
express his theory that ancient tragedy was entirely sung was Girolamo Mei. In 1573 Mei wrote to his former teacher Pietro Vettori who was preparing a commentary on Aristotle's Politics his opinion and view on the uses of music in tragedy, comedy, satire, and dithyramb. According to his opinion the performance of ancient tragedy concluded music in all its parts. These comments were contained the fourth book of Mei's work on the modes of ancient music, which had been in progress since 1568. The manuscript in the Vatican Latin collection (5323) is entitled Hieronymi Meij Fiorentini De Modis musicis antiquorum ad Petrum Victoriarum Libri iiii. Cf. p. 18: „Melicorum poetarum permista genera extiterunt, qui omnes tum ab instrumentorum diversitate tum a suo poemate appellari consueverunt. In citharoedes enim et aulaedos primum sunt dispersiri; quod si ad citharum aut lyram, ad Tibiam isti, quam aulos graeci dicunt sua poemata canere instituerunt. Hic vero illud non est omittendum Tragoedos et Comoedos perpetua Tibijs usos fuisse: quod etiam et de satyris, ni fallor, est existimandum." See also Hanning 1973, 249 ff.

${ }^{22}$ For more details see Hanning 1973, 251. Rinuccini's contact with these theories can be proved through his collaboration with Bardi in the 1589 intermezzi - on this collaboration that increased Rinuccini's interest in the power of ancient music see Hanning 1973, 256 ff. - as well as through his membership in the Alterati academy (see below), which included Bardi, Jacopo Corsi and Girolamo Mei. 
of note values is abundant. ${ }^{23}$ Instruments placed backstage provided a basso continuo accompaniment: a harpsichord, a large lira (a bowed instrument), a large lute and a chitarrone. Eight years later, in the preface to his own setting of Rinuccini's Dafne, the composer Marco da Gagliano (1582-1643) would refer to Peri's "discovery" as "that artful manner of sung speech that all Italy admires". ${ }^{24}$ In this "sung speech," a singer delivered a recitative melody with an actor's dramatic and oratorical skills, presenting the dramatic poetry in a clear and comprehensible form; thus achieving the goal of providing emotional impact to the text through the support of music, so that the audience will receive pleasure from the scenic experience. ${ }^{25}$

The idea of tragic pleasure is Aristotelian. According to Aristotle poetry, music and drama aim at pleasing their audience, which watches and listens to an imitation of life, of people in action. Although separated from the lives and fortunes of the represented characters it is moved by them, but its emotional state never becomes dangerously painful, since the audience is well aware that what happens is not real but only a representation of reality. ${ }^{26}$ In this respect Aristotle discards monstrous and unnatural spectacles from tragedy, which rather shock than move. It is exactly what La Tragedia in Rinuccini's Prologue refuses to follow pointing indirectly to the Senecan drama, which was very influential throughout the $16^{\text {th }}$ century. Rinuccini, seems to include pity and fear in his Tragedia following Aristotle, who in his Poetics declares: "The poet should produce the pleasure that comes from pity and fear by means of imitation" (1453b12).

The Aristotelian theories on the mimetic function and power of music and drama impelled predominantly two groups of humanists, musicians, poets and intellectuals in late Renaissance Florence. The first was the group of Alterati, founded in 1569, whose members regularly met at the palace of Giovanni Battista Strozzi the Younger to discuss topics and subjects like Aristotle's Poetics, Francesco Patrizi's new commentary on the Poetics, the verse-forms suitable to tragedy, how rhetoric and poetry moved the passions, and what tragic catharsis signified. Its members included Giovanni Bardi, Ottavio Rinuccini, Jacopo Corsi, who contributed music to Peri and Rinuccini's Dafne and sponsored their Euridice, Prince Giovanni de' Medici, Girolamo Mei and Giovanni Battista Doni, author of the Trattato della musica

${ }^{23}$ Palisca 2003, 3.

${ }^{24}$ See Rosow 2005, 209; Brown 1970, 401-43.

${ }^{25}$ In his Poetics written in 1529, the playwright Trissino already noted that the first, and consequently one of the most important, elements of a tragedy is its scenery because this might excite pleasure in the audience.

${ }^{26}$ See predominantly Sifakis 2001, $83 \mathrm{ff}$. 
scenica (1638). The other group, actually a subunit of the Alterati, was called Camerata and its members gathered under the patronage of Count Giovanni de' Bardi (in the 1570 a and 1580s) and then, after his departure from Florence in 1592, of Jacopo Corsi (both, like Rinuccini, were members of the Accademia degli Alterati). ${ }^{27}$ Among the most important documents of these activities was a seminal series of writings born of the collaboration between Vincenzo Galilei (whose musical studies were sponsored by Bardi) and the Florentine humanist Girolamo Mei who, after Boethius, was the first European who investigated the ancient Greek music theory. His pioneering research into Greek music was of great significance and had a decisive influence on the emergence of monody and music drama. In 1572 Galilei wrote to Mei a list of problems, foremost concerning ancient music, that he had not been able to solve. ${ }^{28}$ Why does modern music no longer seem to be able to produce the amazing and unique effects described by the ancients? Mei's answer developed an original and radical idea. The ancients did not know polyphony. His study of the sources had led him to the conclusion that their music must have been exclusively monophonic; Greek music consisted always of a single line, even if several sang and played together or many sang in a chorus. This was the"secret"of the marvellous power of ancient music to move listeners. He stated, we should not expect our music to achieve a goal it does not set itself to achieve, for ancient (monophonic and languageoriented) music aimed to arouse the passions of the soul as an enhanced manifestation of the natural communicative functions and properties of language, whereas modern (polyphonic) music aims only at pleasing the ear. ${ }^{29}$ In the fourth book of his thorough study on Greek Music De modis (completed in 1573) Mei examines the practice of the tonoi and harmoniae and their place in education, moral conduct and therapeutics, as well as their use in tragedy, comedy, satyr plays and dithyramb. In that book Mei expresses his theory that the ancient tragedies and comedies were sung in their entirety, accompanied in unison by the aulos, a theory that was very influential in literary and musical circles. So the group of Camerata believed that the music of the ancient time had possessed a great power to ennoble

\footnotetext{
${ }^{27}$ Selected Bibliography on the Alterati and the florentian Camerata: Donington 1981, 79 ff.; Ewen 1971, 491; Grout 1947, 43; Palisca 1989, 3 ff.; Randel 1986; Schrade 1950, 40 ff.

${ }^{28}$ Between 1572 and 1581 Mei exchanged more than 30 letters with Vincenzo Galilei, a correspondence from which Galilei learnt many things about Greek music.

${ }^{29}$ Polyphony, with its many parts, "conveys to the soul of the listener at the same time diverse and contrary affections as it mixes indistinctly together melodies and modes that are completely dissimilar and of natures contrary to each other" (Palisca 1960, 73). Counterpoint, he maintained, had developed out of a desire of musicians to show off their prowess and was useless for anything else, particularly for the expression of the feelings and meanings of a text.
} 
its listeners not only because it was monodic but also it had given greater weight to the text. The members of this Florentine group often devalued contemporary music, particularly the forms of polyphony in madrigals, where many different melodies superimposed atop each other, because it confused listeners and lacked any power to spur its audience to virtuous living. For these reasons, the recitative style dominated the early operas performed in and around Florence. ${ }^{30}$

In 1586, Lorenzo Giacomini delivered a discourse on tragic purgation to the academy. According to Giacomini, we take four types of pleasure in tragedy: of learning about the events and the incredible things, appreciation of the play as imitation, reflection on the compassion we feel for the characters on stage and our freedom from their "fearful adventures" and the experience of "pleasures accessory to cathartic process" itself. ${ }^{31}$

Giacomini follows the physiological implications of Aristotle's claim that those who listen to enthusiastic music during sacred rites and tragic festivals are "restored ... as though they had received a cure and catharsis". ${ }^{32}$ Aristotle stresses the power of music, as part of pleasure due to its mimetic nature and the fact that rhythm and melody supply imitations (ónot $\omega \mu \alpha \tau \alpha)$ of anger and gentleness, also of courage and temperance, and of all the qualities contrary to these, and of other qualities of character ( $\ddot{\eta} \theta \eta)$, which hardly fall short of the actual affections (Pol. 1340a14-24). ${ }^{33}$ The music can underline these differences, stress and bring them out in their particularity, if they are relevant to a poetical work. In listening to such strains our souls are altered (1340a22). According to Aristotle catharsis has to be a pleasurable

\footnotetext{
${ }^{30} \mathrm{~V}$. Galilei played an important role in attempts to revive an historically accurate style of Greek performance. Galilei himself developed the first attempts to fashion recitative. He experimented with recitative, setting to monodic lines selections from Dante's Divine Comedy. He set up the human ear as the final arbiter of taste in music and his example actually inspired Ottavio Rinuccini and Jacopo Peri.

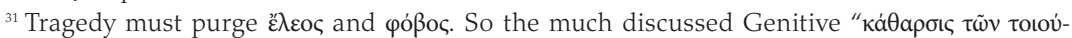
$\tau \omega v \pi a \theta \eta \mu \alpha \dot{\tau} \omega v^{\prime \prime}$ (Poetics 1449b27f.) should be interpreted as a genitivus obiectivus: Tragedy must purge these affects, not purge from these affects (as genitivus separativus). Cf. Zeppezauer 2011, 26 n.89, who argues for a genitivus obiectivus. Her exposition and remarks on catharsis and emotions (25 ff.) are clearly arranged. See also Tsitsiridis 2010, 35 ff. On these philological questions see Kommerell 1984, 268 ff.; Dirlmeier 1940, 81-92. On the Renaissance theatre and the theories of tragedy in the $16^{\text {th }}$ century see Reiss 2008, $235 \mathrm{ff}$.

${ }^{32}$ Hoxby 2005, 264.

${ }^{33}[\ldots]$ [...

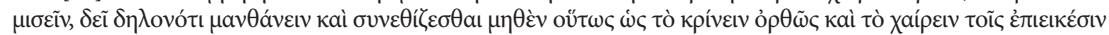

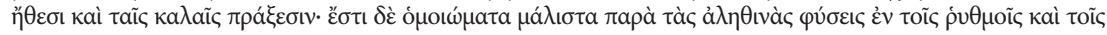

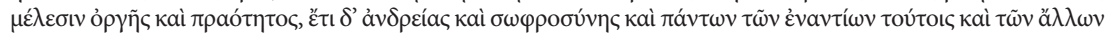

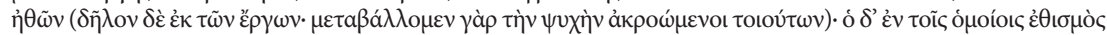

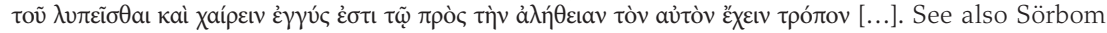
$1994,41 \mathrm{ff}$.
} 
relief following the excitation of certain emotions produced by the representations of music which affect our moral dispositions (cf. 1342a11-17). ${ }^{34}$

Giacomini argues that the passion of a hero represented on stage acts like a sympathetic medication, ${ }^{35}$ raising up our own passions and dissolving them by lamenting or weeping. ${ }^{36}$ The same had been pointed out by Giovanni Battista Giraldi Cinzio (1504-1573), well known not only as the founder of the modern Italian Tragedy but also as the author of an important series of Discorsi on tragedy, comedy, epic poetry, and pastoral theatre. Cinzio was the first to attempt a systematic codification of modern tragedy on the basis of conceptual criteria defined in the Poetics: "tragedy has a pleasure of its own, and in that weeping (pianto) one discovers a hidden pleasure, which makes it pleasing to the listener, attracts the attention of the soul, and fills it with marvel."

The lament as a musical topos possessed a high status in European literature. Expressive rhetoric and affective imagery were its special characteristics. In Madrigals, qualified as lamenti, the genre postulated musical importance around the turn of the $17^{\text {th }}$ century stressing on the theoretical authorization of the new monodic style. ${ }^{37}$ Theorists such as Giacomini, Mei and Vincenzo Galilei chose in fact the lament in outlining and determining the cathartic effect of that style; due to its emotional intensity, it was the type of text which could move an audience to pity, purging them in this way of strong passions. Librettists and composers of early opera recognised the special dramatic position and affective character of the lamento, differentiating it from the narrative of the rest of the text: librettists demanded greater formality through using more strongly metred and rhymed texts in which particularly affective lines often reappeared as refrains; and composers wrote music to these texts with greater freedom, repeating or otherwise amplifying and elevating affective words or phrases with melodic sequence or dissonance, often enforcing a tonal coherence to produce structural autonomy. ${ }^{38}$

\section{${ }^{34}$ Sifakis 2001, $90 \mathrm{ff}$.}

${ }^{35}$ Antonio Sebastiano Minturno had already emphasized in his 1559 De poeta on catharsis as analogous to medical purging, arguing that by such violent emotions as pity and fear tragedy ejects these and all others: ambition, lust, anger, avarice, pride, fury, and "unbridled desire".

${ }^{36}$ Affective sympathy caused the passion represented to arouse and eject the same passion in the spectator. Giacomini 1972, 347-71 (see esp. pp. 354-5). See also Hoxby 2005, 264.

${ }^{37}$ Such lamenti for example: Stefano Rossetto's Lamento di Olimpia (1567) and B. S. Nardò's Lamento di Fiordeligi (1571).

${ }^{38}$ One of the most effective and influential of early 17th-century lamenti was Monteverdi's Lamento d'Arianna from his opera to a libretto by Ottavio Rinuccini, performed in Mantua in 1608. This lamento was soon isolated from its context and presented separately. Monodic Ariadne laments were published by Severo Bonini (1613), Possenti (1623) and F.A. Costa (1626) and by Monteverdi 
There is no doubt that in the antiquity Euripides was the most renowned composer of monodies, especially of laments, famous for his affective power of his libretto-like sung texts, being the forefront of the "new music". In Euripides' tragedies, as in the kitharoedic nomoi of his friend Timotheus, by whom he was influenced, $5^{\text {th }}$ century Greek music reached the climax of its development. Plutarch and Lucian record stories which pay tribute to Euripides's music indicating his popularity in Hellenistic Greece and the Roman Empire. ${ }^{39}$ His monodies demanded virtuosi soloists with coloratura skills and their vividness and range of emotion suggest a powerful use of rhythm and melody. ${ }^{40}$ With his monodies Euripides sought to move his audience with stirring music and words that excited pity. Euripides's restless metrical experimentation showed that he was interested in heightening the emotional tension by intensification, in immediate effect as the members of the Florentian Camerata, and nowhere more so than in the laments of his characters. He left numerous examples of such laments most of them astrophic, especially in the late plays, written with varying degrees of structure, interjected vocatives, repetitive exclamations of emotive adjectives, repetition of phrasing for pathetic effect, unexpected variation. The music of these laments shaped throughout to express all the emotional nuances of the words. An astrophic song was much harder to learn than song in repeated metres and so it was associated with the solo voice rather than the choruses (cf. Ps.-Arist., Probl. 19.15) ${ }^{41}$ and gave the chance for ornamen-

in his own reworking of the piece as a madrigal (1614), the publication of the monodic version (1623) and his adaptation of the madrigal to a sacred text (1640). Monteverdi's monodic lamento has not a closed form, without predetermined musical structures as the aria. It is highly expressive and therefore suitable for expressing uncontrolled passion. See Epstein 1927-8, 216-22; Westrup 1940, 144-54; Gallico 1967, 29-42; Barblan 1967, 217-28; Fortune 1968, 183-97; Porter 1995, 73-110.

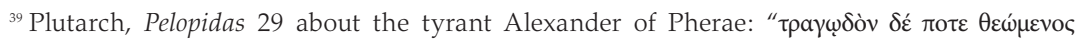

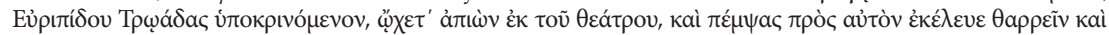

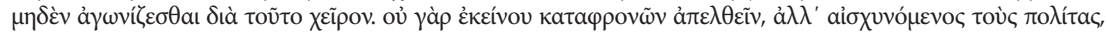

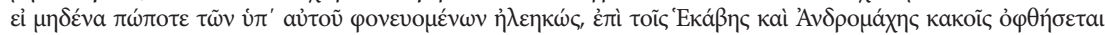

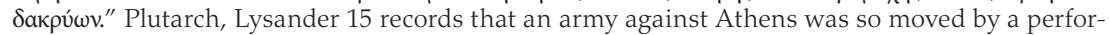

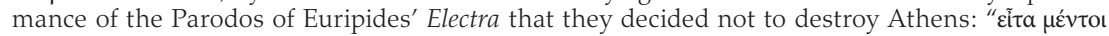

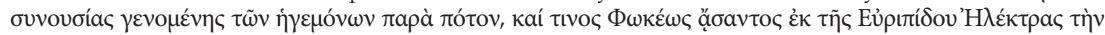

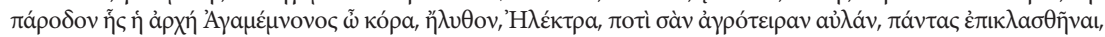

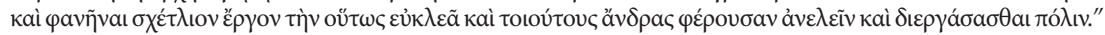
Lucian, Hist. Conscr. 1 reports about a performance of Euripides' Andromeda during the reign

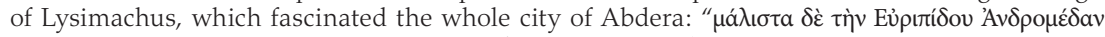

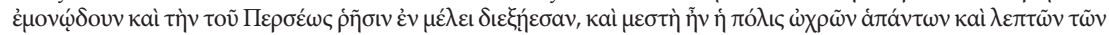

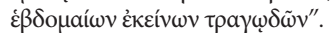

${ }^{40}$ See Owen 1936, 148-54; Collard 1981, 24 f.

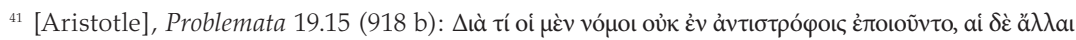

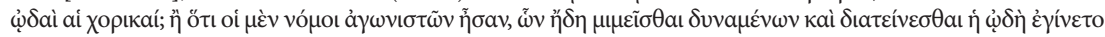

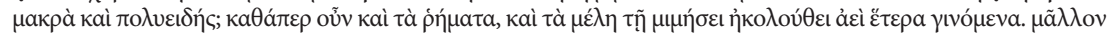

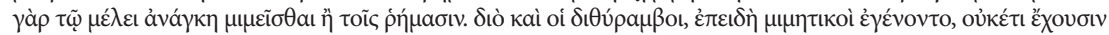

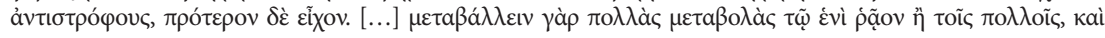


tation and expression of affects. ${ }^{42}$ I would like to mention some of these monodies, which contain all the above features that enable the audience to follow the movement of the singing characters' thoughts and the agitation of their passions: Kreusa's monody in Ion (vv. 859 ff.), explaining her suffering caused by the rape can been seen as the emotional and structural centre of the play, ${ }^{43}$ Hermione's melodramatic desperate song in Andromache (vv. $825 \mathrm{ff}$.) held mostly in dochmiacs, the most agitated of the lyric metres, associated with strong emotions such as grief, horror and despair ${ }^{44}$ in dialogue with the nurse, who speaks in iambic trimeters seeking to reason with her, exaggerating so the impassioned dochmiacs. ${ }^{45}$ Electra's solo aria about her whole family saga in Orestes (982 ff.) ${ }^{46}$ and her informal lament for herself, her father and her brother recalling in detail the horror of her father's murder in Electra (112 ff. $)^{47}$ or Helen's really melodious long mourning in Helen (164 ff. $)^{48}$ and not least Cassandra's monody (a mad song) in a mixture of dochmiac metre, resolved iambics and glyconics in Troades (308 ff.). ${ }^{49}$ And the lament of the dying Hippolytus for his plight in the Hippolytus (1347 ff.), whose metrical shifts and transitions from non melic anapaestic dimeters or spoken iambic trimeters to melic anapaests and lyric iambs increases his agitation forming high points of sympathetic identification with the hero. ${ }^{50}$ The pastiche, a parody of the Euripidean monody (vv. 1329-63), which Aeschylus in the Frogs by Aristophanes sings, is very instructive of the method and practice of the Euripidean lament. ${ }^{51}$

The audience experiences similar passions when it listens to the lament - monodies of Euridice: Orfeo's first lament in the second scene, after Dafne's report of the death of Euridice and with Orfeo hinting that he wishes to join her in death: "Non piango e non sospiro, / o mia cara Eurid-

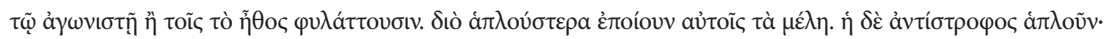
ả

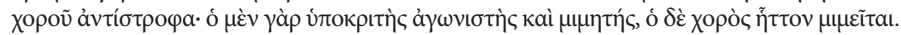

${ }^{42}$ On the language of the Euripidean monodies see Barlow 1986, $10 \mathrm{ff}$.

${ }^{43}$ On Kreusas's Monody (Ion 859 - 922) see Lee 1997, 254 ff., with bibliography.

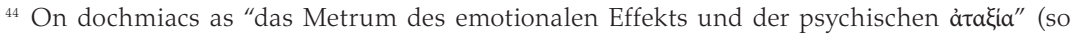
Kannnicht 1973, 123) see especially Conomis 1964, 23 ff; Del Grande 1960, 368 ff.; Korzeniewsky 1968, 170 ff.; West 1982, 108 ff.; Sicking 1993, 187 ff.

${ }^{45}$ See Stevens 2001, 194 ff.; Allan 2002, 67 ff.

${ }^{46}$ West 1990, 251 ff.; Willink 1989, 245 ff.

${ }^{47}$ See Cropp 1988, 107 ff.

${ }^{48}$ Cf. for instance the repetition of the same words (vv. 173; $195 ; 207 ; 214 ; 331 ; 365 ; 366 ; 384$ ), the idyllic scenery of the first and the third antistrophe and the repetition of the news that Helen

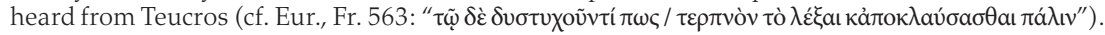

${ }^{49}$ Cf. Barlow 1997, 173 ff.

${ }^{50}$ Cf. Barrett 1964, 402 ff.; Halleran 2000, 262 ff.

${ }^{51}$ See Dover 1997, 217 ff. 
ice, che sospirar, che lacrimar non posso ...",52 Orfeo's second lament in the Underworld in the fourth scene: "Funeste piaggie, ombrosi orridi campi" and his last lament in the same scene, as he tries to please Pluto with his song: "Ahi! Che pur d'ogni legge", where features of the Euripidean monody make their appearance such as interjected vocatives ("o mia cara Euridice", "o mio core, o mia speme, o pace, o vita!", "Misero!"), repetitive exclamations (Ohimè! ... Ohimè!, "Dhe"), repetitive exclamations of emotive adjectives ("o cara vita, o cara morte!) repetition of phrasing ("Chi mi t'ha tolto / Chi mi t'ha tolto", "Non son, non son lontano", "senti, mia vita, senti", "quai pianti e quai lamenti", "mira, signor, dhe mira" ..."mira, signor, dhe mira"), variations ("funeste piagge, ombrosi orridi campi", ombre d'inferno", "tenebrosi orrori", "come trafiggha amor, come tormenti", "quest'ombre intorno e quest'oscuri nummi"). Needless to say that all possible synonyms for weeping, lamenting und pity occur in these laments.

We must also take in consideration that $\mathrm{Cinzio}^{53}$ and Giacomini ${ }^{54}$ select Iphigenia in Tauris for discussion, a play that many critics prefer to characterise as a "romantic melodrama", to show what Aristotle meant by the "best" (ottima) manner of tragic fable and that tragedies like Iphigenia in Tauris, in which recognition averts a violent deed, are the "best" kind

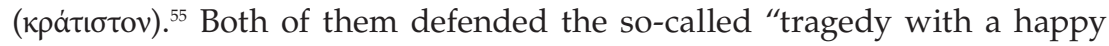
ending" as the dramatic structure most appropriate to modern theatrical practice. Giraldi highly recommends tragedies a lieto fine in his Discorso, arguing that tragic plots with happy endings are especially marked by the recognitions prized by Aristotle, who especially values recognitions that transform bad fortune into good. For Giacomini tragedies that proceed from

\footnotetext{
${ }^{52}$ I cite for example a musicological analysis of this lament from Taruskin 2010, 7 f.: "Orpheus's lament is set with great subtlety, all conveyed by musical 'modulations' to match the modulations of his mood. He goes from numb shock ('I neither weep nor sigh...') through a sudden outpouring of grief ('O my heart! O my hope...') to firm resolve. The first section has a particularly static bass to match Orpheus's initial torpor. The second section, where lethargy gives way to active distress, is introduced by a brusque harmonic disruption: the cadential 'Phrygian' E major replaced out of nowhere by 'Dorian' G minor. This most anguished section of the lament has the highest dissonance quotient. Orpheus's lines seem altogether uncoordinated with the bass harmonies. He leaves off after 'Ohimè!' (Ah, me!) with a gasp, his line dangling on an A over the bass G. The bass having changed to D as if to accommodate the A, Orpheus reenters ('Dove si gita?'/'Where have you gone?') with a new contradiction, on E. The bass once again moves to accommodate the E, which becomes the cadence harmony. The third section begins with the same disruption as the second: a G-minor chord impinging on the cadential E major. This time, however, the G minor moves through the circle of fifths to a cadence on F, the 'Lydian', still the symbol - after eight hundred years! - of mollitude (the primary association by now is not to Plato's resurrected theorizing but to everyone's daily experience in church). At the same time the bass begins to bestir itself iconically, moving rhythmically as one does when animated by determination."

${ }^{53}$ Giraldi Cinzio 1973, 183 f. See also Javitch 2008, 63 f.

${ }^{54}$ Giacomini 1597, 29-52, esp. $51 \mathrm{f}$.

${ }_{55}$ Aristotle, Poetics 1454a.
}

Let. Cláss., São Paulo, n. 16, p. 61-83, 2012 
misery to felicity can be purgative because the prospect of an impending evil can move us as powerfully as a present one. Giacomini seems to conclude that the tragedian's essential duty is to move audiences to extremes of pity and fear without letting them fall into a horrified petrifaction, just as La Tragedia implies in the first two stanzas of the Prologue.

Apart from Iphigenia in Tauris we also find romantic qualities in Ion, in Orestes and especially in Helen. In each of them there is romance, excitement, danger, suspense and a happy ending. In Helen a man and a woman, separated by war, disaster and misunderstandings, are finally reunited and, after overcoming many more obstacles together, they at last reach home and live happily ever after, the happiest of happy endings. Thus Euripides runs his audience through a gamut of sensations to a final tonic chord of satiety and satisfaction. It is actually less an example of a new genre than a subversion of an old one. It seems to me that La Tragedia points out the same in the Prologue of Euridice.

Another element in the libretto of Euridice is the part of the messenger, much beloved by Euripides. Two of the three messenger speeches in Euridice, that is Daphne's heart-rending account of Euridice's death and Arcetro's report that Orfeo, having found the spot at which Euridice died, did not kill himself but was taken away by Venere are distinguished by their quite pictorial beginnings, their ekphraseis, the ordered narrative in strict chronological sequence, their fragments of recorded speeches and their graphic descriptions of the climactic actions in visual terms. Although the messenger reports in Euridice are not held by impartial witnesses - Daphne, Arcetro and Aminta otherwise act their own parts -, they are comparable to the Euripidean ones reducing the fear of tragic action and requiring an emotional response.

All the debates, discussions and musical experiments of the previous twenty years in the Academia degli Alterati and in the Camerata Fiorentina, that is the well established tradition of courtly intermedii, as well as various attempts to set isolated dramatic scenes to music and the concern about the nature of pastoral drama coupled with the desire to rediscover the ancient emotional power of music bore fruit at the performance of Euridice. But I would maintain more generally that many music historians, among them N. Pirrotta, ${ }^{56}$ Barbara Russano Hanning ${ }^{57}$ R. Taruskin,${ }^{58}$ in claiming that the

\footnotetext{
${ }^{56}$ E.g. Pirrotta et Povoledo 1975, 276-333, esp. 329; Pirrotta et Povoledo 1982, 237-80, esp. 264.

${ }^{57}$ Hanning 1973, 246.

${ }^{58}$ Taruskin 2010, 10: "And indeed, the play is made to end happily: Orpheus gets Eurydice back with no strings attached; there is no second death, no second loss. The play remains, as it had to, within the boundaries of the dramatized favola pastorale, the pastoral play, a light genre that did not exist in classical times. Not only would a truly tragic representation have been unfit for a
} 
depiction of tender passions and the happy ending - characteristics mentioned in the Prologue of Euridice - point out the pastoral parentage of the opera, failed to notice that these formal characteristics of opera might as well be traced to Euripides's tragedies. As Hoxby rightly mentions, ${ }^{59}$ they also represent passionate love, frequently end happily and more often introduce a deus ex machina to engineer the felicitous catastrophe - compare in this respect the end of Orfeo by Strigio and Monteverdi with the appearance of Apollo. I do not even deny that such "sweeter emotions" are to be found in the long-standing tradition of the Renaissance philosophy of love. But this love - sorrow of modern tragedy has its counterpart in Euripides, thus transforming the revival of ancient tragedy into the birth of melodrama. Early opera contributed to extricating its tragic style from Seneca's deformation of it with its egocentric, violent, evil, guilt-ridden and unheroic characters, who constantly anticipate and predict the advent of horrors and thereafter directly follow grotesque blood sacrifices of innocent victims creating disorienting vastness and emotional turbulence. So Euridice might be the pastoral equivalent of Aristotle's description of the effect of tragedy, which purged the emotions by sympathetic feelings of pity and terror.

With Euripides' musical representation of the passions, his episodic plotting, his choral interludes and his felicitous catastrophes, not only our Euridice but also the Baroque opera of the $17^{\text {th }}$ and the $18^{\text {th }}$ century - with Euripides playing a chief role in the operatic repertory with his lost and his surviving tragedies - can be seen as a coherent reading of a set of his tragedies. In them the tragic affection is not necessarily that of - metaphorically speaking - wet eyes, tissues and goose bumps, but they represent deep, stirring, pressing emotions yet they still contain a reflective moment something that was recognised by the first commentators of the Aristotelian theories on drama and music. Even if we claim that the subjects, dramatic structure and philosophical background of early operas stem from a combination of Roman comedy, Roman (esp. Vergilian) pastoral and Ovid's epic, as R. C. Ketterer ${ }^{60}$ argues, nevertheless we should also bear in mind the great influence of Euripides on these genres. Euripides's love-sorrow along with his heroic-sorrow reveals his majesty as the most tragic of the poets, a prestige of which he was deprived by the emergence of the German ideal-

festivity of state, but Ovid's mythological romance could never have supported one. In a tragedy a hero falls in consequence of a flaw; an accidental death like Eurydice's is by no classical definition a tragic one (even if Orfeo does lack the ultimate in self-control). The early musical plays did not - could not - aspire to the tragic style. Tragic opera came later, and elsewhere."

${ }^{59}$ Hoxby 2005, 267.

${ }^{60}$ Ketterer 2003, $1 \mathrm{ff}$. 
ism in the late eighteenth and nineteenth centuries, which forced out the passions from their central place in the critical analysis of tragedy. ${ }^{61}$

In Euridice melody dominates the musical discourse and does so exclusively in the service of the affetti expressed in the text, in whose favour the unity and metre of the verse are often sacrificed as they are in Euripides' monodies. Sensitive to every nuance of Rinuccini's libretto Peri wrote a music that mirrored the rhetoric of the words while also embodying their affective content, thus revealing the emotional power of the drama.

\section{REFERENCES}

Allan, W. 2002. The Andromache and Euripidean Tragedy. Oxford. (1 ed. 2000).

Barblan, G. 1967. "Un ignoto 'Lamento d'Arianna' mantovano." RIM 2:217-28.

Barlow, Shirley A. 1986. "The language of Euripides' Monodies." In Studies in Honour of T.B.L. Webster, edited by J. H. Betts, J. T. Hooker and J. R. Green, 10-22. Bristol.

Barlow, Shirley A. 1997. Euripides. Trojan Women. With Translation and Commentary. Wiltshire. (1 ed. 1986).

Barrett, W. S. 1964. Euripides. Hippolytos. Edited with Introduction and Commentary. Oxford.

Boyle, A. J. 1997. Tragic Seneca. An Essay in the Theatrical Tradition. London, New York.

Braden, Gordon. 1985. Renaissance Tragedy and the Senecan Tradition: Anger's Privilege. New Haven Conn., Yale University Press.

Brown, H. M. 1970. "How Opera Began: an Introduction to Peri's Euridice (1600)." In The Late Italian Renaissance, 1525-1630, edited by E. Cochrane, 401-43. London. (Reprinted in Garland Library of the History of Western Music, edited by E. Rosand, New York, 1985).

Bujić, Bojan. 1991. "'Figura Poetica Molto Vaga': Structure and Meaning in Rinuccini's Euridice." Early Music History 10:29-64.

Carter, T. 1992. Music in Late Renaissance and Early Baroque Italy. London: B.T. Batsford.

Collard, C. 1981. Euripides. Oxford. ("Greece and Rome" New Surveys in the Classics n. 14)

Conomis, N. 1964. "The dochmiacs of Greek drama." Hermes 92:23-50.

Cropp, M. J. 1988. Euripides. Electra. With Translation and Commentary. Wiltshire.

Del Grande, C. 1960. La metrica greca. Turin. (Enciclopedia classica sez. II vol. 5).

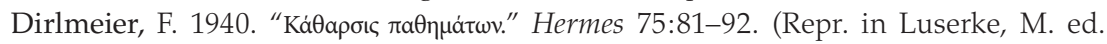
1991. Die Aristotelische Katharsis. Dokumente und ihrer Deutung im 19. und 20. Jahrhundert, 220-231. Hildesheim/Zürich/New York, 1991. [Olms Studien 30]).

Donington, R. 1981. The Rise of Opera. New York: Scribner.

Dover, K. 1997. Aristophanes. Frogs. Edited with Introduction and Commentary. Oxford.

${ }^{61}$ Vgl. Hoxby 2005, 269.

Let. Cláss., São Paulo, n. 16, p. 61-83, 2012 
Epstein, P. 1927. "Dichtung und Musik in Monteverdis 'Lamento d'Arianna'." ZMw 10:216-22.

Ewen, D. 1971. "Opera." In The New Encyclopedia of the Opera. New York: Hill And Wang.

Fortune, N. 1968. "Monteverdi and the Seconda Prattica: Monody." In The Monteverdi Companion, edited by D. Arnold and N. Fortune, 183-97. London. (2 ed. 1985 as The New Monteverdi Companion).

Gallico, C. 1967. "I due pianti di Arianna di Claudio Monteverdi." Chigiana 4 (n.s.): $29-42$.

Giacomini, Lorenzo. 1972. "De la purgazione de la tragedia." In Trattati di poetica e retorica del Cinquecento, edited by B. Weinberg, vol. 3, 347-71. Bari: Laterza.

Giacomini, Lorenzo Tebalducci Malespini. 1597. Orationi e discorsi. Fiorenza: Case de Sermartelli.

Giraldi Cinzio, G. B. 1973. Scritti critici. A cura di C. G. Crocetti. Milan: Marzorati.

Grout, D. J. 1947. A Short History of Opera: One-Volume Edition. Columbia: Columbia University Press.

Halleran, M. R. 2000. Euripides. Hippolytus. With Introduction, Translation and Commentary. Wiltshire (1 ed. 1995).

Hanning, Barbara Russano. 1973. "Apologia pro Ottavio Rinuccini." Journal of the American Musicological Society 26:240-4.

Hansen, Jette Barnholdt. 2003. "From Invention to Interpretation: The Prologues of the First Court Operas. Where Oral and Written Cultures Meet." The Journal of Musicology 20:556-96.

Harness, Kelley. 2003. "Le tre Euridici: Characterization and Allegory in the Euridici of Peri and Caccini." Journal of Seventeenth-Century Music 9.

Herrick, M. T. 1965. Italian Tragedy in the Renaissance. Urbana, Ill..

Hill, E. D. 2002. "Revenge Tragedy." In A Companion to Renaissance Drama, edited by A. F. Kinney. Oxford, Malden, Massachusetts.

Hoxby, Blair. 2005. "The Doleful Airs of Euripides: The Origins of Opera and the Spirit of Tragedy Reconsidered." Cambridge Opera Journal 17(3):253-69.

Javitch, D. 2008. "The assimilation of Aristotle's Poetics in sixteenth-century Italy." In The Cambridge History of Literary Criticism, vol. 3: The Renaissance, edited by G. P. Norton, 55-65. Cambridge. 4 ed. (1 ed. 1999).

Kannicht, R. 1973. “Review of Korzeniewski 1968." Gnomon 45:113-34.

Ketterer, R. C. 2003. "Why early opera is Roman and not Greek." Cambridge Opera Journal 15:1-14.

Kirkendale, W. 1993. The Court Musicians in Florence during the Principate of the Medici. Florence: Leo S. Olschki. ("Historiae Musicae Cultores" Biblioteca 61)

Kommerell, M. 1984. Lessing und Aristoteles. Untersuchung über die Theorie der Tragödie. Frankfurt a. M.

Korzeniewsky, D. 1968. Griechische Metrik. Darmstadt.

Lanson, G. 1904. "L'idée de la tragédie en France avant Jodelle." RHL 11(4):541-85.

Lee, K. H. 1997. Euripides. Ion. With Introduction, Translation and Commentary. Wiltshire.

Leopold, Silke. 2003. “Die Anfänge von Oper und die Probleme der Gattung." Journal of Seventeeth-Century Music 9.1. 
Lucas, F. L. 2009. Seneca and Elizabethan Tragedy. Cambridge. (1 ed. 1922).

McGee, T. J. 1982. "Orfeo and Euridice, the First Two Operas." In Orpheus: The Metamorphoses of a Myth, edited by J. Warden, 163-81. Toronto.

Owen, A. S. 1936. "The date of the Electra of Sophocles." In Greek Poetry and Life (Essays presented to Gilbert Murray), ed. Cyril Bailey et al., 145-157. Oxford: The Clarendon Press.

Palisca, C. V. ed. 1960. Girolamo Mei (1519-1594): Letters on Ancient and Modern Music to Vincenzo Galilei and Giovanni Bardi. MSD, iii. (2 ed. 1977).

Palisca, C. V. 1968. "The Alterati of Florence, Pioneers in the Theory of Dramatic Music." In New Looks at Italian Opera Essays in Honor of Donald J. Grout, edited by W. Austin, 9-38. Ithaca.

Palisca, C. V. 1989. The Florentine Camerata: Documentary Studies and Translations (Music Theory Translation Series). New Haven, CT: Yale Univ. Press.

Palisca, C. V. 2003. "Aria Types in the Earliest Operas." Journal of Seventeenth-Century Music 9.1.

Pirrotta, Nino. 1954a. "Temperaments and Tendencies in the Florentine Camerata." The Musical Quartely 40(2):169-89.

Pirrotta, Nino. 1954b. "Tragédie et comédie dans la camerata fiorentina." In Musique et poésie au XVIe siècle. Paris: CNRS.

Pirrotta, Nino; E. Povoledo. 1969. Li due Orfei. Turin. (2 ed. 1975).

Pirrotta, Nino; E. Povoledo. 1982. Music and Theatre from Poliziano to Monteverdi. Cambridge.

Porter, W. 1995. "Lamenti recitativi da camera"; "Con che soavità". In Studies in Italian Opera, Song and Dance, 1580-1740, edited by I. Fenlon and T. Carter, 73-110. Oxford.

Randel, D. ed. 1986. "Camerata." The New Harvard Dictionary of Music, Vol. 3. Cambridge, Massachusetts: Harvard University Press.

Reiss, T. J. 2008. "Renaissance Theatre and the Theory of Tragedy." In The Cambridge History of Literary Criticism, vol. 3: The Renaissance, edited by G. P. Norton, 229-47. Cambridge. 4 ed. (1 ed. 1999).

Rosow, Lois. 2005. "Power and display: Music in Court Theatre." In The Cambridge History of Seventeenth-Century Music, edited by Tim Carter and John Butt, 197-240. Cambridge.

Schiesaro, A. 2003. The Passions in Play. Thyestes and the Dynamics of Senecan Drama. Cambridge.

Schild, Marion. 1933. Die Musikdramen Ottavio Rinuccinis. Munich.

Schrade, L. 1950. Monteverdi: Creator of Modern Music. New York: W. W. Norton \& Co.

Sicking, C. M. J. 1993. Griechische Verslehre. München.

Sifakis, G. M. 2001. Aristotle on the Function of Tragic Poetry. Crete University Press.

Solerti, A. 1903. Le origini del melodramma. Turin. (Repr. 1969)

Sörbom, G. 1994. "Aristotle on Music as Representation." The Journal of Aesthetics and Art Criticism 52(1):37-46.

Staley, G. A. 2010. Seneca and the Idea of Tragedy. Oxford.

Stevens, P. T. 2001. Euripides. Andromache. Edited with Introduction and Commentary. Oxford. (1 ed. 1971).

Tarrant, R. J. 2004. Seneca: Agamemnon. Cambridge. 2 ed. (1 ed. 1976). 
Taruskin, R. 2010. "Pressure of Radical Humanism." In Music from the Earliest Notations to the Sixteenth Century. Oxford. (Oxford History of Western Music.)

Treherne, M. 2007. “The Difficult Emergence of Pastoral Tragicomedy: Guarini's Il pastor fido and its Critical Reception in Italy, 1586-1601." In Early Modern Tragicomedy, edited by Subha Mukherji and Raphael Lyne, 28-42. Boydell \& Brewer.

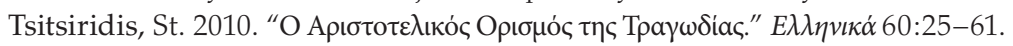

West, M. L. 1982. Greek Metre. Oxford.

West, M. L. 1990. Euripides. Orestes. Edited with Translation and Commentary. Wiltshire. (1 ed. 1987).

Westrup, J. A. 1940. "Monteverdi's 'Lamento d'Arianna'." MR 1:144-54.

Willink, C. W. 1989. Euripides. Orestes. With Introduction and Commentary. Oxford.

Zeppezauer, Dorothea. 2011. Bühnenmord und Botenbericht. Zur Darstellung des Schrecklichen in der griechischen Tragödie. Berlin/Boston/Göttingen.

\begin{abstract}
$*$
Abstract. Without denying the influence of Renaissance theatrical practice, especially the "tragi-comedia pastorale" on the birth and development of the opera, I argue that Rinuccini aims at a rebirth of the ancient Tragedy in his Prologue of Euridice, the first surviving Opera (1600), well aware that his production was not a historically accurate reconstruction of ancient Greek tragedy. As we see from the Prologue, on one hand $\mathrm{La}$ Tragedia retains in her repertoire sighs, tears, laments from a purely human point of view wanting to awake sweeter emotions of the heart, on the other hand she aims at a catharsis through a happy end of the story. I am not convinced that our poet in his prologue rejects the catharsis effect of the Greek tragedies and that his opus stands in opposition to the Aristotelian precepts for tragedy as many musicologists and music historians think. In this Prologue, that is actually a recusatio, I think that Rinuccini wants his Tragedia to illuminate the nature of the pleasure that the audience derives from the experience of tragedy. The emphasis of La Tragedia on the purely affective has more to do with features of the Euripidean dramaturgy than the Senecan tragedy, which became the greatest force in the moulding of Renaissance Tragedy.
\end{abstract}

Keywords. Ottavio Rinuccini; Jacopo Peri; Euridice; prologue; Euripides; Seneca. 